\title{
In Situ Analysis of Copper Alloys by Femtosecond Laser Ablation Inductively Coupled Plasma Mass Spectrometry: Constrains on Matrix Effects
}

\author{
Germán Velásquez ${ }^{1,2 *}$, Anastassia Y. Borisova ${ }^{3,4}$, Sandrine Baron5 ${ }^{5}$ Luc Robbiola ${ }^{5}$ \\ ${ }^{1}$ Advanced Mining Technology Center (AMTC), FCFM, Universidad de Chile, Santiago, Chile \\ ${ }^{2}$ Universidad Central de Venezuela, Instituto de Ciencias de la Tierra, Caracas, Venezuela \\ ${ }^{3}$ Géosciences Environnement Toulouse, Université de Toulouse, UPS OMP-CNRS, Toulouse, France \\ ${ }^{4}$ Geological Department, Lomonosov Moscow State University, Moscow, Russia \\ ${ }^{5}$ Université de Toulouse, CNRS, Laboratoire TRACES (UMR 5608), Toulouse, France \\ Email: *gevelasqueza@gmail.com
}

How to cite this paper: Velásquez, G., Borisova, A.Y., Baron, S. and Robbiola, L. (2018) In Situ Analysis of Copper Alloys by Femtosecond Laser Ablation Inductively Coupled Plasma Mass Spectrometry: Constrains on Matrix Effects. American Journal of Analytical Chemistry, 9, 150-161.

https://doi.org/10.4236/ajac.2018.93013

Received: January 18, 2018

Accepted: March 12, 2018

Published: March 15, 2018

Copyright $\odot 2018$ by authors and Scientific Research Publishing Inc. This work is licensed under the Creative Commons Attribution International License (CC BY 4.0).

http://creativecommons.org/licenses/by/4.0/

(c) $\underset{\mathrm{EY}}{\mathrm{EY}}$ Open Access

\begin{abstract}
Direct analysis of copper-base alloys using laser ablation techniques is an increasingly common procedure in cultural heritage studies. However, main discussions remain focused on the possibility of using non-matrix matched external reference materials. To evaluate the occurrence of matrix effects during in situ microanalysis of copper-base materials, using near infrared femtosecond laser ablation techniques (NIR fs-LA-ICP-MS), two bronzes, i.e., $(\mathrm{Sn}-\mathrm{Zn})$-ternary and $(\mathrm{Sn})$-binary copper-matrix reference materials, as well as a reference synthetic glass (NIST-SRM-610) have been analyzed. The results have been compared to data obtained on a sulfide-matrix reference material. Similar values in relative sensitivity averages of ${ }^{63} \mathrm{Cu},{ }^{118} \mathrm{Sn}$ and ${ }^{66} \mathrm{Zn}$, as well as in ${ }^{118} \mathrm{Sn} /{ }^{63} \mathrm{Cu}$ and ${ }^{66} \mathrm{Zn} /{ }^{63} \mathrm{Cu}$ ratios were obtained, for all analyzed matrix types, i.e., copper-base-, silicate-, and sulfide-reference materials. Consequently, it is possible to determinate major and minor element concentrations in copper alloys, i.e., $\mathrm{Cu}, \mathrm{Sn}$ and $\mathrm{Zn}$, using silicate and sulfide reference materials as external calibrators, without any matrix effect and over a wide range of concentrations (from wt.\% to ppm). Equally, $\mathrm{Cu}, \mathrm{Sn}$ and $\mathrm{Zn}$ concentrations can be precisely determined in sulfides using homogeneous alloys (reference) materials as an external calibrator. Thus, it is possible to determine $\mathrm{Cu}, \mathrm{Sn}$ and $\mathrm{Zn}$ in copper-base materials and their ore minerals, mostly sulfides, in a single analytical session, without requiring specific external calibrators for each matrix type. In contrast, immiscible elements in copper matrix, such as $\mathrm{Pb}$ and $\mathrm{Fe}$
\end{abstract}


show notable differences in their relative sensitivity values and ratios for different matrix-materials analyzed, implying that matrix-matched external calibrations remain to be applied for their trace quantification.

\section{Keywords}

Copper Alloys, Reference Material, Matrix Effect, In-Situ Metal

Determinations, Near-Infrared Femtosecond Laser Ablation-Inductively

Coupled Plasma-Mass Spectrometry (NIR fs-LA-ICP-MS)

\section{Introduction}

In recent years, it has been highlighted the importance about application of laser ablation based-analytical techniques to characterize metals-bearing materials. It is specially the case for cultural heritage studies [1] [2], such as on bronze objects [3] [4] [5] [6] [7], due to the quasi non-destructive sampling and the ability to acquire multi-elemental data for major, minor and trace element concentrations with excellent detection limits.

The main impediment to develop laser ablation-inductively coupled plasma-mass spectrometry (LA-ICP-MS) applications on solid copper-base (bronze) alloys has been due to a lack of well-characterized, homogeneous, and matrix-matched reference materials [5] [6], which have been developed more specifically for micro-analytical purposes on whole-sample analyses [6]. In cultural heritage, the use of femtosecond (fs-)LA-ICP-MS technique has not been a common practice; as an example there is a recent study, which was conducted on ancient Chinese manufactured gold materials [8]. It is proposed that fs-LA-ICP-MS technique is suitable to measure in situ element concentrations at least as accurate and precise as classical in whole-sample ICP-MS methods [8]. Femtosecond (fs) laser ablation-based techniques are considered less prone to have matrix-related problems than nanosecond (ns) techniques [9]-[14]. Thus is because the fs-laser technique has a mechanical rather than a thermal influence on the ablated matrix [15] [16] [17] [18].

In a previous study [19], it was showed the possibility of quantifying major and trace element concentrations in natural materials, i.e., sulfide minerals, using a synthetic silicate glass (NIST-SRM-600) as an external calibrator, without any matrix effect, between sulfide and silicate matrices, over a wide range of concentrations (from wt.\% to ppm), when a NIR femtosecond laser ablation coupled with ICP-MS is used. Even more, it was also proposed the possibility to determine precisely $\mathrm{Au}$ and $\mathrm{Cu}$ concentrations in silicate materials using homogeneous sulfide (reference) materials as an external calibrator [19]. These results point towards a new mode of analyzing both metal-bearing materials and its corresponding ore-minerals, in a single analytical session.

The possibility to apply non-matrix matched calibration for quantification of trace element concentrations (at $10^{2}$ to $10^{5} \mathrm{ppm}$ level) in Fe-base (stainless steel) 
samples has been also showed [20], using both ultraviolet (UV-) ns-LA-ICP-MS and (UV-) fs-LA-ICP-MS.

Additionally, the (UV-) ns-LA-ICP-MS technique has been applied on entrapped slag inclusions in Roman iron bars [21] [22], discovered in Mediterranean wrecks, to track the ancient trade routes with great success. Nevertheless, it is required to cut a piece of these iron cultural heritage material to search and analyze the inclusions. Using of (UV-) fs-LA-ICP-MS technique, this weakness in the sample preparation might be avoided due to the possibility to measure in situ element concentrations directly on iron metal.

In contrast, some studies [23] have showed that it is not possible to quantify $\mathrm{Cu}$ isotope ratios in sulfides by NIR fs-LA-MC-ICP-MS analyses, using a metal NIST-SRM-976 as an external calibrator. Instead, the authors used in-house made matrix-matched calibrators.

In order to evaluate the possibility of quantifying major, minor and trace element concentrations in copper-base alloys using non-matrix matched reference materials, during near infrared femtosecond laser ablation techniques (NIR fs-LA-ICP-MS), we performed detailed analyses of two copper-based alloys (Cu-Sn-Zn-ternary and $\mathrm{Cu}$-Sn-binary alloys) and a synthetic glass reference material (NIST-SRM-610). Additionally, our results will be compared with those obtained previously [19] on a natural (made-in-house) chalcopyrite reference material (Cpy-RM), calibrated with a synthetic glass (NIST-SRM-610) applying the same laser ablation system and analytical conditions than for this study [19]. Finally, we discuss the possibility of using no-matrix matched reference materials, i.e., copper-base, sulfide- and silicate-matrices, as external calibrators; to precisely determinate the concentrations of the major, minor, and trace elements (i.e., $\mathrm{Cu}, \mathrm{Sn}, \mathrm{Zn}, \mathrm{Fe}$ and $\mathrm{Pb}$ ) in bronze alloys.

\section{Materials and Micro-Analytical Technique}

To carry out this study the following materials were analyzed: 1) a ternary bronze alloy (named $\mathrm{B} 3 \mathrm{Z9P}$ ) with $\mathrm{Cu}, \mathrm{Zn}$ and $\mathrm{Sn}$ as major elements, and $\mathrm{Pb}, \mathrm{Fe}$, $\mathrm{P}(550 \mathrm{ppm}), \mathrm{Ni}(1500 \mathrm{ppm})$ as trace elements; 2$)$ a binary tin bronze alloy (named $\mathrm{B} 6 \mathrm{P}$ ) with $\mathrm{Cu}$ and $\mathrm{Sn}$ as major elements, $\mathrm{Zn}$ as a minor element, and $\mathrm{Pb}$, $\mathrm{Fe}, \mathrm{P}$ (880 ppm), Ni (50 ppm) as trace elements; and 3) the NIST-SRM-610 reference material [24]. $\mathrm{Cu}, \mathrm{Sn}, \mathrm{Zn}, \mathrm{Fe}$ and $\mathrm{Pb}$ weight concentrations are given in Table 1 for both bronze alloys (B6P and B3Z9P) reference materials, as well as for NIST-SRM-610 and the previously analyzed natural chalcopyrite (Cpy-RM, [19]) reference material. The elemental composition of B6P (CEN CW452K or UNS C51900) and B3Z9P (CEN CW454K or UNS C42500) alloys was determined by ICP-OES (Perkin Elmer Optima 5300 DV) for the main elements $(\geq 1$ wt.\%), and by ICP-MS (Perkin Elmer Elan 9000) for minor and trace elements $(<1 w t . \%)$. Compositional heterogeneity, expressed as standard deviations, for all the measured elements in alloys was lower than the instrumental error of 5\% (Table 1). The copper-base materials are homogeneous single-phase alloys. They 
Table 1. Reference material composition.

\begin{tabular}{lcccc}
\hline & B3Z9P & B6P & NIST-SRM-610 [24] & Cpy-RM [19] \\
& {$[$ this study] } & [this study] & & \\
\hline $\mathrm{Cu}$ & $89.2 \pm 4.5 \mathrm{wt} . \%$ & $93.9 \pm 4.7 \mathrm{wt} . \%$ & $430.3 \pm 23.6 \mathrm{ppm}$ & $34.97 \pm 0.12 \mathrm{wt} \%$ \\
& $(\mathrm{RSD}=5 \%)$ & $(\mathrm{RSD}=5 \%)$ & $(\mathrm{RSD}=5.5 \%)$ & $(\mathrm{RSD}=0.3 \%)$ \\
$\mathrm{Sn}$ & $2.5 \pm 0.1 \mathrm{wt} . \%$ & $5.9 \pm 0.3 \mathrm{wt} . \%$ & $396.3 \pm 17.8 \mathrm{ppm}$ & \\
& $(\mathrm{RSD}=4 \%)$ & $(\mathrm{RSD}=5 \%)$ & $(\mathrm{RSD}=4.5 \%)$ & Not analyzed \\
$\mathrm{Zn}$ & $8.02 \pm 0.4 \mathrm{wt} . \%$ & $0.2 \pm 0.01 \mathrm{wt} . \%$ & $456.3 \pm 19.2 \mathrm{ppm}$ & \multirow{2}{*}{ Not analyzed } \\
& $(\mathrm{RSD}=5 \%)$ & $(\mathrm{RSD}=5 \%)$ & $(\mathrm{RSD}=4.2 \%)$ & \\
$\mathrm{Fe}$ & $300 \pm 15 \mathrm{ppm}$ & $98 \pm 4.9 \mathrm{ppm}$ & $457.1 \pm 22.2 \mathrm{ppm}$ & $30.27 \pm 0.17 \mathrm{wt} . \%$ (RSD \\
& $(\mathrm{RSD}=5 \%)$ & $(\mathrm{RSD}=5 \%)$ & $(\mathrm{RSD}=4.9 \%)$ & $=0.6 \%)$ \\
$\mathrm{Pb}$ & $39 \pm 2 \mathrm{ppm}$ & $60 \pm 3.0 \mathrm{ppm}$ & $413.3 \pm 15.4 \mathrm{ppm}$ & Not analyzed \\
& $(\mathrm{RSD}=5 \%)$ & $(\mathrm{RSD}=5 \%)$ & $(\mathrm{RSD}=3.7 \%)$ & \\
\hline
\end{tabular}

correspond to the fcc $\alpha(\mathrm{Cu})$ solid solution, in which the $\mathrm{Sn}$ and $\mathrm{Zn}$ alloying elements can be considered randomly distributed at the copper crystal lattice points [25].

Ablation intensity spectra have been obtained using a NIR fs laser ablationinductively coupled plasma-quadrupole mass spectrometry at the Géosciences Environnement Toulouse (GET) laboratory in Toulouse, France. During analyses, the following isotopes were monitored: ${ }^{57} \mathrm{Fe},{ }^{63} \mathrm{Cu},{ }^{66} \mathrm{Zn},{ }^{118} \mathrm{Sn}$ and ${ }^{208} \mathrm{~Pb}$.

At GET laboratory, the ablated material is carried out in a flow of a mixed helium $(\mathrm{He})$ and argon ( $\mathrm{Ar}$ ) gases in the transporting tube connected to a quadrupole ICP-MS (Agilent 7500ce; Agilent Technologies, Santa Clara, CA, United States). A Ti:sapphire laser (Pulsar 10; Amplitude Technologies, Evry, France) was used operating at $800 \mathrm{~nm}$ and providing 55 fs pulses with a maximum output of $12 \mathrm{~mJ}$ pulse $^{-1}$ [19] [26] [27] [28]. During analyses, the laser Gaussian beam was focused using a $\times 1.75$ microscope objective with an energy of $1 \mathrm{~mJ}$ pulse $^{-1}$, yielding ablation pits of ca. $100 \mu \mathrm{m}$ diameter. Tuning was optimized for minimal molecular oxide species (typically ${ }^{232} \mathrm{Th}^{16} \mathrm{O} /{ }^{232} \mathrm{Th}=1.1 \%$ ) and doubly charged ion species (typically ${ }^{140} \mathrm{Ce}^{++} /{ }^{140} \mathrm{Ce}^{+}<2 \%$ ) production [19]. Analyses lasted $90 \mathrm{~s}$ integrating a gas blank measured during the first $30 \mathrm{~s}$ and followed by $60 \mathrm{~s}$ of sample analysis. The same conditions were applied to analyze the made-in house CPy-RM and the NIST-SRM-610 reference materials [19].

\section{Results}

Time-resolved fs LA-ICP-QMS spectra for monitored isotopes, i.e., ${ }^{57} \mathrm{Fe},{ }^{63} \mathrm{Cu}$, ${ }^{66} \mathrm{Zn},{ }^{118} \mathrm{Sn}$ and ${ }^{208} \mathrm{~Pb}$, in B3Z9P and B6P alloy reference materials are showed in Figure 1. Intensity (in counts per seconds) and sensitivity (relative to the bulk reference concentrations in ppm) average values, measured for ${ }^{57} \mathrm{Fe},{ }^{63} \mathrm{Cu},{ }^{66} \mathrm{Zn}$, ${ }^{118} \mathrm{Sn}$ and ${ }^{208} \mathrm{~Pb}$, in all analyzed reference materials are presented in Table 2.

Copper is the main containing element in the studied alloy materials. Results (Table 2) show that calculated ${ }^{63} \mathrm{Cu}$ sensitivity average values are similar to each other: $19 \pm 0.1 ; 17 \pm 1.4$; and $17.6 \pm 0.4$, for all analyzed materials, i.e., the binary-(B6P) and ternary-(B3Z9P) bronzes and NIST-SRM-610, respectively. For 
Table 2. Intensity (in counts per seconds) and sensitivity (relative to the bulk reference concentrations in ppm) average values for alloys (B3Z9P, and B6P), sulfide (Cpy-RM), and silicate glass (NIST-SRM-610 in both analytical sessions) reference materials. NC, not calculated.

\begin{tabular}{|c|c|c|c|c|c|c|}
\hline \multicolumn{2}{|c|}{$\begin{array}{c}\text { Reference } \\
\text { material }\end{array}$} & B3Z9P [this study] & $\begin{array}{c}\text { B6P } \\
\text { [this study] }\end{array}$ & $\begin{array}{c}\text { NIST } \\
\text { [this study] }\end{array}$ & Cpy-RM [19] & NIST [19] \\
\hline \multirow{5}{*}{ 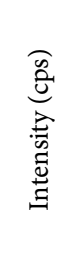 } & ${ }^{57} \mathrm{Fe}$ & $261 \pm 11$ & $80 \pm 12$ & $495 \pm 5$ & $1,165,769 \pm 226,022$ & $1330 \pm 144$ \\
\hline & ${ }^{63} \mathrm{Cu}$ & $15,717,971 \pm 319,406$ & $15,514,774 \pm 1,351,712$ & $8185 \pm 45$ & $261,971 \pm 3,634,596$ & $28,356 \pm 3563$ \\
\hline & ${ }^{66} \mathrm{Zn}$ & $785,289 \pm 31,516$ & $15,408 \pm 2230$ & $4757 \pm 74$ & NC & NC \\
\hline & ${ }^{118} \mathrm{Sn}$ & $497,993 \pm 15,947$ & $1,029,682 \pm 88,635$ & $8180 \pm 49$ & $\mathrm{NC}$ & $28,389 \pm 864$ \\
\hline & ${ }^{208} \mathrm{~Pb}$ & $1129 \pm 42$ & $3160 \pm 86$ & $18,477 \pm 101$ & NC & $60,541 \pm 4953$ \\
\hline \multirow{5}{*}{ 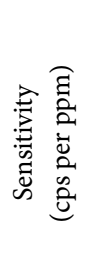 } & ${ }^{57} \mathrm{Fe}$ & $0.87 \pm 0.04$ & $0.8 \pm 0.1$ & $1.1 \pm 0.002$ & $4 \pm 1$ & $2.9 \pm 0.3$ \\
\hline & ${ }^{63} \mathrm{Cu}$ & $17.6 \pm 0.4$ & $17 \pm 0.4$ & $19 \pm 0.1$ & $75 \pm 10$ & $66 \pm 8$ \\
\hline & ${ }^{66} \mathrm{Zn}$ & $9.8 \pm 0.4$ & $9.5 \pm 1.3$ & $10.4 \pm 0.2$ & $\mathrm{NC}$ & $\mathrm{NC}$ \\
\hline & ${ }^{118} \mathrm{Sn}$ & $19.8 \pm 0.6$ & $17 \pm 1.5$ & $21 \pm 0.1$ & $\mathrm{NC}$ & $72 \pm 2$ \\
\hline & ${ }^{208} \mathrm{~Pb}$ & $28.9 \pm 1.1$ & $47 \pm 1.3$ & $45 \pm 0.2$ & $\mathrm{NC}$ & $146 \pm 12$ \\
\hline
\end{tabular}

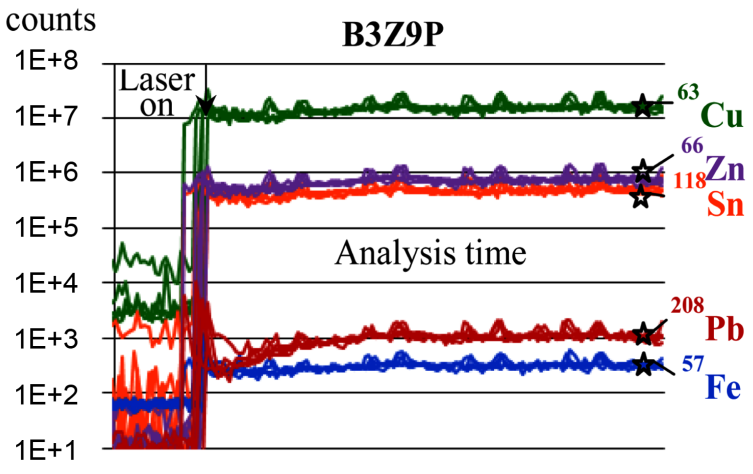

(a)

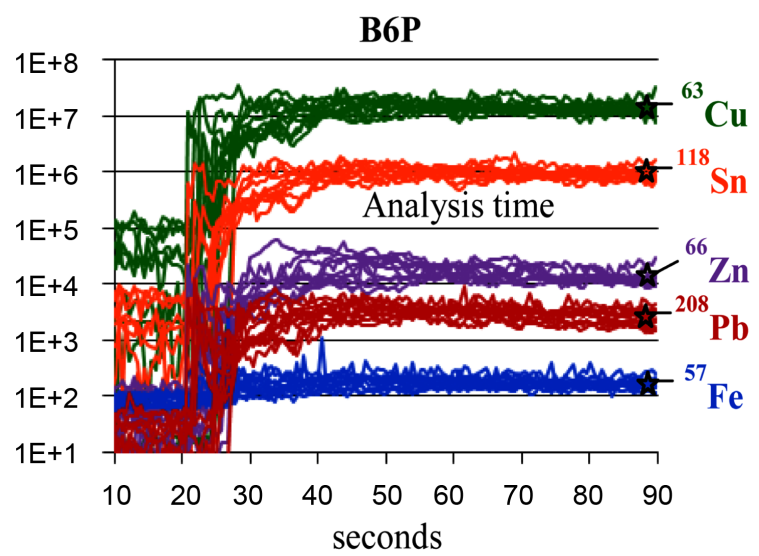

(b)

Figure 1. Typical NIR femtosecond LA-ICP-MS output from microanalysis of (a) B3Z9P and (b) B6P alloy reference materials.

the previous session $[19],{ }^{63} \mathrm{Cu}$ sensitivity average values reported were $66 \pm 8$, and $75 \pm 10$, for NIST-2012 and Cpy-RM, respectively, which also are in the 
same order of magnitude.

Zinc can be considered as a main element in B3Z9P, a minor element in B6P and a trace element in NIST-SRM-610. Results (Table 2) show that ${ }^{66} \mathrm{Zn}$ sensitivity average values for all analyzed materials are very similar to each other: 9.8 \pm 0.4 for B3Z9P, $9.5 \pm 1.3$ for B6P and $10.4 \pm 0.2$ for NIST. Thus, Zn element displays regularity in values regardless of the analyzed matrix type. This similarity in values is also spread over a wide range of element concentrations (from wt.\% to ppm).

In the other hand, $\mathrm{Fe}$ and $\mathrm{Pb}$ trace elements for all analyzed materials, display average sensitivity values very scattered among themselves (Table 2 ).

To evaluate the relationship between the major, minor and trace analyzed elements, the values for ${ }^{118} \mathrm{Sn} /{ }^{63} \mathrm{Cu}$ (Figure $2(\mathrm{a})$ ), ${ }^{66} \mathrm{Zn} /{ }^{63} \mathrm{Cu}$ (Figure 2(b)), ${ }^{57} \mathrm{Fe} /{ }^{63} \mathrm{Cu}$ (Figure $3(\mathrm{a})$ ), and ${ }^{208} \mathrm{~Pb} /{ }^{63} \mathrm{Cu}$ (Figure $3(\mathrm{~b})$ ) average sensitivity ratios, calculated for each analyzed reference material, are plotted versus the bulk concentration ratios.

Figure 2(a) shows the same average values of ${ }^{118} \mathrm{Sn} /{ }^{63} \mathrm{Cu}$ sensitivity ratio for NIST-SRM-610, measured in both sessions: $1.1 \pm 0.1$ (this study) and $1.1 \pm 0.01$ [19]. Likewise, both $\alpha$-bronze alloys display very close ${ }^{118} \mathrm{Sn} /{ }^{63} \mathrm{Cu}$ average sensitivity ratio values: $1.1 \pm 0.1$ and $1.1 \pm 0.03$, for binary $(\mathrm{B} 6 \mathrm{P})$ and ternary bronzes(B3Z9P) respectively. In a same way, Figure 2(b) displays very similar ${ }^{66} \mathrm{Zn} /{ }^{63} \mathrm{Cu}$ average sensitivity ratios for all analyzed reference materials: $0.55 \pm$ 0.02 for B3Z9P, $0.57 \pm 0.10$ for B6P and $0.55 \pm 0.09$ for NIST-SRM-610. Equality

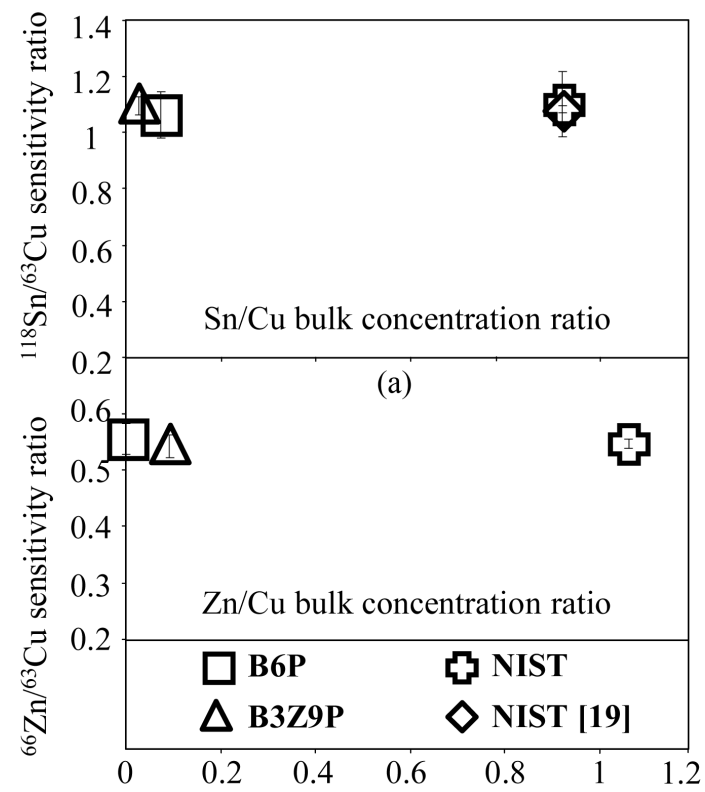

(b)

Figure 2. (a) $\mathrm{Sn} / \mathrm{Cu}$ average sensitivity ratios vs. $\mathrm{Sn} / \mathrm{Cu}$ bulk concentration ratio for alloys (B6P and B3Z9P) and NIST-SRM-610 reference materials. For comparison, also shown are the values obtained previously [19] for NIST-SRM-610; (b) $\mathrm{Zn} / \mathrm{Cu}$ average sensitivity ratios vs. $\mathrm{Zn} / \mathrm{Cu}$ bulk concentration ratio for alloys (B6P and B3Z9P) and NIST-SRM-610 reference materials. 
observed in values is regardless of the type of analyzed matrix. Interestingly, these results do not show variations even though $\mathrm{Zn}$ is a major element in B3Z9P-, a minor element in B6P-, and a trace element in NIST-SRM-610-reference materials.

In Figure $3(\mathrm{a}),{ }^{57} \mathrm{Fe} /{ }^{63} \mathrm{Cu}$ average sensitivity ratios expose some differences: $0.057 \pm 0.004$ (NIST-SRM-610 -this study), $0.044 \pm 0.003$ (NIST-SRM-610, [19]), $0.049 \pm 0.001$ (B3Z9P), $0.048 \pm 0.006$ (B6P) and $0.051 \pm 0.004$ (Cpy-RM, [19]). According to these results, there are slight variations in Fe-sensitivity ratios related to different analyzed matrix types, i.e., copper-base, sulfide- and silicate-matrices.

In the same direction, calculated ${ }^{208} \mathrm{~Pb} /{ }^{63} \mathrm{Cu}$ average sensitivity ratios are well dispersed (Figure 3(b)), when they are plotted as a function of the $\mathrm{Pb} / \mathrm{Cu}$ bulk concentration ratios, displaying the following values: $2.3 \pm 0.0$ (NIST-SRM-610-this study), $2.2 \pm 0.3$ (NIST-SRM-610, [19]), $2.9 \pm 0.2$ (B6P), and $1.6 \pm 0.1$ (B3Z9P).

\section{Discussion}

Our results show that ${ }^{63} \mathrm{Cu}$ sensitivity values (cps per $\mathrm{ppm}$ ) are similar to each other for all analyzed reference materials regardless of the matrix types, i.e., copper-base, sulfide- and silicate glass-matrix reference materials. Additionally, calculated ${ }^{118} \mathrm{Sn} /{ }^{63} \mathrm{Cu}$ and ${ }^{66} \mathrm{Zn} /{ }^{63} \mathrm{Cu}$ average sensitivity ratios (Figure 2 ) are also

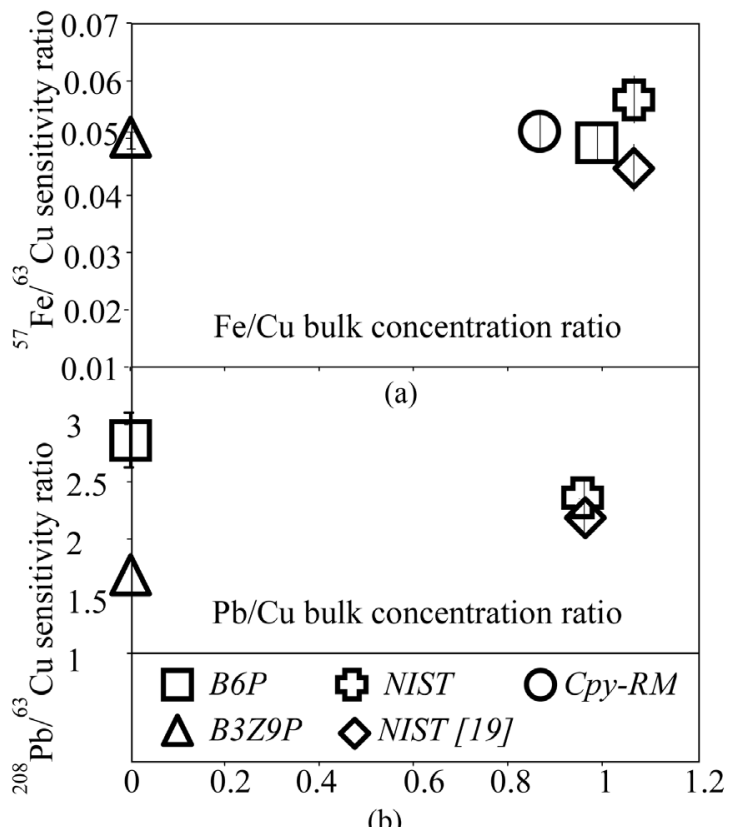

Figure 3. (a) $\mathrm{Fe} / \mathrm{Cu}$ average sensitivity ratios vs. $\mathrm{Fe} / \mathrm{Cu}$ bulk concentration ratio for alloys (B6P and B3Z9P) and silicate glass (NIST-SRM-610) reference materials. For comparison, also shown are the values obtained for both sulfide (Cpy-RM, [19]) and silicate glass (NIST-SRM-610, [19]) reference materials; (b) $\mathrm{Pb} / \mathrm{Cu}$ average sensitivity ratios vs. $\mathrm{Pb} / \mathrm{Cu}$ bulk concentration ratio for alloys (B6P and B3Z9P) and silicate glass (NIST-SRM-610) reference materials. For comparison, also shown are the values for silicate glass (NIST-SRM-610, [19]). 
very similar for the different types of matrix analyzed in this study. The similarity of these values is particularly remarkable, considering that $\mathrm{Cu}$ and Sn correspond to main elements in concentration (wt.\%) for bronze alloys (B6P and $\mathrm{B} 3 \mathrm{Z9P}$ ) and sulfide natural material (Cpy-RM), while they correspond to trace elements in concentration (ppm) for the synthetic silicate glass reference material. In a same way, $\mathrm{Zn}$ is a major element (wt.\%) in B3Z9P and it is a minor element (concentered in ppm levels) in B6P. The similarity obtained for $\mathrm{Cu}, \mathrm{Sn}$ and $\mathrm{Zn}$ sensitivity average ratios can be explained considering that the two analyzed bronzes (B3Z9P and $\mathrm{B} 6 \mathrm{P})$ are substitutional $(\mathrm{Cu})$ solid solution phase, in which the alloying elements $(\mathrm{Sn}$ and/or $\mathrm{Zn})$ are randomly distributed in the $\mathrm{fcc}(\mathrm{Cu})$ lattice [25].

These results mean that it is possible to quantify precisely major $(\mathrm{Cu}, \mathrm{Sn}$ and $\mathrm{Zn}$ in $\mathrm{B} 3 \mathrm{Z9P}$ ) and minor ( $\mathrm{Zn}$ in $\mathrm{B} 6 \mathrm{P})$ element concentrations in copper-matrix alloy materials, using silicate glass and/or sulfides minerals, as external reference calibrators. Interestingly, it is also possible to determine precisely $\mathrm{Cu}, \mathrm{Sn}$ and $\mathrm{Zn}$ concentrations in natural sulfides using silicate and/or alloys (reference) materials as an external calibrator. Such quantification method can be very useful if a chemical correlation between bronze materials and their ore minerals is tracked, via quantification of an ore-pathfinder element in both alloys and $\mathrm{Cu}-\mathrm{Sn}-\mathrm{Zn}$ bearing minerals, mostly sulfides, in a single analytical session.

These results provide new insights for in situ analysis of cultural heritage materials and copper-base nanomaterials, which have diverse and heterogeneous matrix types, e.g., sulfides, oxides, silicates and metal phases, often co-existing in a large concentration range [29] [30]. The possibility to measure: 1) low concentration level will avoid destructive sampling, such as inclusions analysis of iron artefacts [22], and 2) wide concentrations ranges will permit heterogeneous copper-base materials to be investigated more efficiently.

As regards the investigation of precious artefacts concerning provenance studies [22], no isotopic data are easily available in practice, but the coupling of (UV-) fs-LA with MC-ICP-MS techniques will offer a new opportunity to measure high resolution isotopic ratios on cultural heritage materials from museums.

In contrast, ${ }^{208} \mathrm{~Pb} /{ }^{63} \mathrm{Cu}$ and, to a lesser extent, ${ }^{57} \mathrm{Fe} /{ }^{63} \mathrm{Cu}$ average sensitivity ratios, do not show similar results, when non-matrix matched materials are compared (Figure 3). In the case of $\mathrm{Pb}$, the results can be attributed to its immiscibility in the $\mathrm{Cu}$-alloys matrix, triggering a $\mathrm{Pb}$ heterogeneous distribution, caused by $\mathrm{Pb}$-phase segregation in $\alpha(\mathrm{Cu})$ solid solution matrix, forming almost pure $\mathrm{Pb}$ nano-inclusions into alloys [6] [25] [31]. For iron, different micro-precipitates in the copper matrix can be formed, such as iron oxide inclusions or $\mathrm{Fe}_{3} \mathrm{P}$ precipitates in phosphorus bronze alloys [25]. Since iron is immiscible in copper solid solution for temperature lower than $700^{\circ} \mathrm{C}$ [32], the different sensitivity ratios can be assigned to different chemical configurations such as possible oxide or phosphide iron.

The observed variations in the lead and, in a lower degree, in iron sensitivity 
ratios suggest that NIR fs-LA-ICP-MS alloy analysis have partial matrix effects. It follows that to carry out in situ analysis of $\mathrm{Pb}$ and $\mathrm{Fe}$ trace elements in copper-base alloys, it is recommended to use a matrix matching reference material.

\section{Conclusions}

This study shows that, using NIR fs-LA-ICP-MS, non-matrix-matched reference materials can be applied including copper-base, silicate- and sulfide-matrix types as external calibrator. This allows to precisely determine major and minor element concentrations, i.e., $\mathrm{Cu}, \mathrm{Sn}$ and $\mathrm{Zn}$ in metallic copper alloys-without any effect of matrix, over a wide range of concentrations (from wt.\% to ppm). Thus reciprocally, it appears possible to determine precisely $\mathrm{Cu}, \mathrm{Sn}$ and $\mathrm{Zn}$ in natural sulfides using homogeneous alloys (reference) materials as an external calibrator. Our results bring forward a simplified and quicker analytical approach to quantify metal element concentrations on alloys as well as on their corresponding metal-bearing ore minerals, for concentrations ranging from wt.\% to ppm, without requiring specific external calibrators for each matrix materials. These new calibration possibilities related to the use of the (UV-) fs-LA-ICP-MS technique offer promising new developments in cultural heritage studies.

In contrast, matrix-matched external calibrations should be applied for quantifying trace elements, e.g., $\mathrm{Pb}$ and $\mathrm{Fe}$, in copper-alloys, using NIR fs-LA-ICPMS. Such capacity of partial stoichiometric probe (only for major and minor elements) using NIR fs-LA-ICP-MS can be called as partial matrix effect.

\section{Acknowledgements}

This work has been supported by Géosciences Environment Toulouse Laboratory (BQR program).

\section{References}

[1] Gratuze, B., Blet-Lemarquand, M. and Barrandon, J.-N. (2001) Mass Spectrometry with Laser Sampling: A New Tool to Characterize Archaeological Materials. Journal of Radioanalytical and Nuclear Chemistry, 247, 645-656. https://doi.org/10.1023/A:1010623703423

[2] Radtke, M., Reiche, I., Reinholz, U., Riesemeier, H. and Guerra, M.F. (2013) Beyond the Great Wall: Gold of the Silk Roads and the First Empire of the Steppes. Analytical Chemistry, 85, 1650-1656. https://doi.org/10.1021/ac3025416

[3] Colao, F., Fantoni, R., Lazic, V. and Spizzichino, V. (2002) Laser-Induced Breakdown Spectroscopy for Semi-Quantitative and Quantitative Analyses of ArtworksApplication on Multi-Layered Ceramics and Copper Based Alloys. Sprectrochimica Acta-Part B: Atomic Spectroscopy, 57, 1219-1234. https://doi.org/10.1016/S0584-8547(02)00054-X

[4] Giussani, B., Monticelli, D. and Rampazzi, L. (2009) Role of Laser Ablation-Inductively Coupled Plasma-Mass Spectrometry in Cultural Heritage Research: A Review. Analytica Chimica Acta, 635, 6-21. https://doi.org/10.1016/j.aca.2008.12.040

[5] Resano, M., Garcia-Ruiz, E. and Vanhaecke, F. (2010) Laser Ablation-Inductively Coupled Plasma Mass Spectrometry in Archaeometric Research. Mass Spectrometry 
Reviews, 29, 55-78.

[6] Walaszek, D., Senn, M., Faller, M., Philippe, L., Wagner, B., Bulska, E. and Ulrich, A. (2013) Metallurgical and Chemical Characterization of Copper Alloy Reference Materials within Laser Ablation Inductively Coupled Plasma Mass Spectrometry: Method Development for Minimally-Invasive Analysis of Ancient Bronze Objects. Spectrochimica Acta-Part B: Atomic Spectroscopy, 79-80, 17-30. https://doi.org/10.1016/j.sab.2012.11.001

[7] Burger, M., Glaus, R., Hubert, V., van Willigen, S., Wörle-Soares, M., Convertini, F., Lefranc, P., Nielsen, E. and Günther, D. (2017) Novel Sampling Techniques for Trace Element Quantification in Ancient Copper Artifacts Using Laser Ablation Inductively Coupled Plasma Mass Spectrometry. Journal of Archaeological Science, 82, 62-71. https://doi.org/10.1016/j.jas.2017.04.009

[8] Brostoff, L.B., González, J.J., Jett, P. and Russo, R.E. (2009) Traces Element Fingerprinting of Ancient Chinese Gold with Femtosecond Laser Ablation-Inductively Coupled Mass Spectrometry. Journal of Archaeological Science, 36, 461-466. https://doi.org/10.1016/j.jas.2008.09.037

[9] Poitrasson, F., Mao, X., Mao, S.S., Freydier, R. and Russo, R.E. (2003) Comparison of Ultraviolet Femtosecond and Nanosecond Laser Ablation Inductively Coupled Plasma-Mass Spectrometry Analysis in Glass, Monazite and Zircon. Analytical Chemistry, 75, 6184-6190. https://doi.org/10.1021/ac034680a

[10] Fernández, B., Claverie, F., Pécheyran, C. and Donard, O.F.X. (2007) Direct Analysis of Solid Samples by fs-LA-ICP-MS. Trends in Analytical Chemistry, 26, 951-966. https://doi.org/10.1016/j.trac.2007.08.008

[11] Koch, J. and Günther, D. (2007) Femtosecond Laser Ablation Inductively Coupled Plasma Mass Spectrometry: Achievement and Remaining Problems. Analytical and Bioanalytical Chemistry, 387, 149-153. https://doi.org/10.1007/s00216-006-0918-Z

[12] Elhassan, A., Giakoumaki, A., Anglos, D., Ingo, G.M., Robbiola, L. and Harith, M.A. (2008) Nanosecond and Femtosecond Laser Induced Breakdown Spectroscopic Analysis of Bronze Alloys. Sprectrochimica Acta B: Atomic Spectroscopy, 63, 504-511. https://doi.org/10.1016/j.sab.2008.02.003

[13] Hirata, T. and Kon, Y. (2008) Evaluation of Analytical Capability of NIR Femtosecond Laser Ablation-Inductively Coupled Plasma Mass Spectrometry. Analytical Sciences, 24, 345-353. https://doi.org/10.2116/analsci.24.345

[14] Horn, I. (2008) Comparison of Femtosecond and Nanosecond Laser Interactions with Geologic Matrices and Their Influence on Accuracy and Precision of LA-ICP-MS Data. Mineralogical Association of Canada Short Course 40, Vancouver, 53-65.

[15] Sylvester, P.J. (2008) Matrix Effects in Laser Ablation-ICP-MS. In: Sylvester, P., Ed., Laser Ablation ICP-MS in the Earth Sciences: Current Practices and Outstanding Issues. Mineralogical Association of Canada, Short Course Series, 40, 67-78.

[16] Seydoux-Guillaume, A.M., Freydier, R., Poitrasson, F., d'Abzac, F.X., Wirth, R. and Datas, L. (2010) Dominance of Mechanical over Thermally Induced Damage during Femtosecond Laser Ablation of Monazite. European Journal of Mineralogy, 22, 235-244. https://doi.org/10.1127/0935-1221/2010/0022-2001

[17] d'Abzac, F.X., Seydoux-Guillaume, A.M., Chmeleff, J., Datas, L. and Poitrasson, F. (2012) In Situ Characterization of Infra-Red Femtosecond Laser Ablation in Geological Samples. Part B: The Laser Induced Particles. Journal of Analytical Atomic Spectrometry, 27, 108-119. https://doi.org/10.1039/C1JA10154D

[18] d'Abzac, F.X., Beard, B.L., Czaja, A.D., Konishi, H., Schauer, J.J. and Johnson, C.M. 
(2013) Iron Isotope Composition of Particles Produced by UV-Femtosecond Laser Ablation of Natural Oxides, Sulfides, and Carbonates. Analytical Chemistry, 85, 11885-11892. https://doi.org/10.1021/ac402722t

[19] Velásquez, G., Borisova, A.Y., Salvi, S. and Beziat, D. (2012) In Situ Au and Cu Microanalysis in Natural Pyrite by Near-Infrared Femtosecond Laser Ablation (fs-LA) Inductively Coupled Plasma Quadrupole Mass Spectrometry (ICP-QMS): No Evidence for Matrix Effect. Geostandards and Geoanalytical Research, 36, 315-324. https://doi.org/10.1111/j.1751-908X.2012.00152.x

[20] Možná, V., Pisonero, J., Holá, M., Kanickỳ, V. and Günther, D. (2006) Quantitative Analysis of Fe-Based Samples using Ultraviolet Nanosecond and Femtosecond Laser Ablation-ICP-MS. Journal of Analytical Atomic Spectrometry, 21, 1194-1201. https://doi.org/10.1039/B606988F

[21] Coustures, M.P., Béziat, D., Tollon, F., Domergue, C. and Long, L. (2003) The Use of Trace Element Analysis of Entrapped Slag Inclusions to Establish Ore-Bar Iron Links: Examples from Two Gallo-Roman Iron-Making Sites in France (Les Martys, Montagne Noire, and les Ferrys, Loiret). Archaeometry, 45, 599-613. https://doi.org/10.1046/j.1475-4754.2003.00131.x

[22] Baron, S., Coustures, M.P., Béziat, D., Guérin, M., Huez, J. and Robbiola, L. (2011) Lingots de plomb et barres de fer des épaves des Saintes-Maries-de-la-Mer (Bouches-du-Rhône, France): Questions de traçabilité comparée. Revue Archéologique de Narbonnaise, 44, 71-98.

[23] Ikehata, K., Notsu, K. and Hirata, T. (2008) In Situ Determination of Cu Isotope Ratios in Copper-Rich Materials by NIR Femtosecond LA-MC-ICP-MS. Journal of Analytical Atomic Spectrometry, 23, 1003-1008. https://doi.org/10.1039/b801044g

[24] Pearce, N.J.G., Perkins, W.T., Westgate, J.A., Gorton, M.P., Jackson, S.E., Neal, C.R. and Chenery, S.P. (1997) A Compilation of New and Published Major and Trace Element Data for NIST SRM 610 and NIST SRM 612 Glass Reference Materials. Geostandards Newsletter. The Journal of Geostandards and Geoanalysis, 21, 115-144. https://doi.org/10.1111/j.1751-908X.1997.tb00538.x

[25] Sidot, E., Kahn-Harari, A., Cesari, E. and Robbiola, L. (2005) The Lattice Parameter of Alpha-Bronzes as a Function of Solute Content: Application to Archaeological Materials. Materials Science and Engineering A, 393, 147-156. https://doi.org/10.1016/j.msea.2004.10.001

[26] Borisova, A.Y., Freydier, R., Polvé, M., Salvi, S., Candaudap, F. and Aigouy, T. (2008) In Situ Multi-Elemental Analysis of the Mount Pinatubo Quartz-Hosted Melt Inclusions by NIR Femtosecond Laser Ablation-Inductively Coupled Plasma-Mass Spectrometry. Geostandards and Geoanalytical Research, 32, 209-229. https://doi.org/10.1111/j.1751-908X.2008.00882.x

[27] Borisova, A.Y., Freydier, R., Polvé, M., Jochum, K.P. and Candaudap, F. (2010) Multi-Elemental Analysis of ATHO-G Rhyolitic Glass (MPI-DING Reference Material) by Femtosecond and Nanosecond LA-ICP-MS: Evidence for Significant Heterogeneity of B, V, Zn, Mo, Sn, Sb, Cs, W, Pt and $\mathrm{Pb}$ at mm-Scale. Geostandards and Geoanalytical Research, 34, 245-255. https://doi.org/10.1111/j.1751-908X.2010.00077.x

[28] Freydier, R., Candaudap, F., Poitrasson, F., Arbouet, A., Chatel, B. and Dupré, B. (2008) Evaluation of Infrared Femtosecond Laser Ablation for the Analysis of Geomaterials by ICP-MS. Journal of Analytical Atomic Spectrometry, 23, 702-710. https://doi.org/10.1039/b709415a

[29] Klein, S. and Hauptmann, A. (1999) Iron Age Leaded Tin Bronzes from Khirbet Edh-Dharih, Jordan. Journal of Archaeological Science, 26, 1075-1082. 
https://doi.org/10.1006/jasc.1999.0412

[30] Ettler, V., Johan, Z., Zavřel, J., Selmi-Wallisová, M., Mihaljevič, M. and Šebek, O. (2015) Slag Remains from the Na Slupi Site (Prague, Czech Republic): Evidence for Early Medieval Non-Ferrous Metals Smelting. Journal of Archaeological Science, 53, 72-83. https://doi.org/10.1016/j.jas.2014.10.007

[31] Korojy, B., Ekbom, L. and Fredriksson, H. (2009) Microsegregation and Solidification Shrinkage of Copper-Lead Base Alloys. Advances in Materials Science and Engineering, 2009, Article ID: 627937. https://doi.org/10.1155/2009/627937

[32] Wang, C.P., Liu, X.J., Ohnuma, I., Kainuma, R. and Ishida, K. (2002) Phase Equilibria in Fe-Cu-X (X: Co, Cr, Si, V) Ternary Systems. Journal of Phase Equilibria, 23, 236-245. https://doi.org/10.1361/105497102770331712 